\title{
Creative Industries Readiness to Support Tourism in Danau Toba
}

\author{
Prihatin Lumbanraja \\ Departemen Manajemen, FakultasEkonomidanBisnis \\ Universitas Sumatera Utara \\ Medan, Indonesia \\ Titinlumbanraja@yahoo.com \\ Beby Kendida Hasibuan \\ Departemen Manajemen, Fakultas Ekonomi dan Bisnis \\ Universitas Sumatera utara \\ Bebykendida08@gmail.com
}

\author{
Arlina Nurbaity Lubis \\ Departemen Manajemen, FakultasEkonomi dan Bisnis \\ Universitas Sumatera Utara \\ Arlinalubis10@gmail.com
}

\begin{abstract}
Indonesia planned to create many of featured tourism destination to promote Indonesia as world's famous tourism destination. In relation with the given strategic plan, Danau Toba was chosen to be one of many featured destination in North Sumatera. In order to achieve the desired outcome, local government, alongside with Danau Toba residences had to improve their tourism selling points, especially creating the tourism experiences. One of supporting factors in tourism experience is the local product which usually branded as souvenirs or many experience-related services. Creative industries was created by combining local value, such as religious, culture, music, and event in form of goods or services. This study aimed to unravel the hidden potential of creative industries to improve tourism experiences. The data was collected through survey and interview based on structured questionnaires. The creative industries potency were mapped within this study. According to this research, The existence of creative industries can support the tourism experience. Creative industries can offers a lot of new experience to the tourist which bring out their best experiences. This approach do not only promote a tourism destination, but also promote many point of local culture to the world. However, the current enterprises of Danau Toba was not ready to develop creative industries further.
\end{abstract}

Keywords - Creative Industries, Visit Indonesia, Tourism Experiecne

\section{INTRODUCTION}

This research is funded by Dana Non-PNBP Universitas Sumatera Utara
Tourism has great potential to spur economic development both for locals and government. Indonesia's tourism sector have been growing steadily since 2012 [1]. One of biggest spot for tourism development in North Sumatera is Danau Toba, especially Samosir Island which located on the mid of Toba Lake. Indonesia's government focused on tourism through 'visit Indonesia' program. The recent development of airport is one of proof that government want to develop Danau Toba as the core attraction for tourism in North Sumatera.

Tourism involved on at least the socio-cultural aspect, economy, and political aspect [2]. The development of tourism destination also plays part as government tools to improve local's income, cut the unemployment rate, supporting the local development, and strengthening diplomatic relationship with other countries [3]. It is regulated under UU No 10/2009. Tourism has a long term impact for economic development.

Danau Toba is chosen for North Sumatera's featured tourism destination for reasons. The Toba Lake is, in fact, the world's second largest lake, first in South East Asia. The scenery had a lot of positive review and praise from many tourist and bloggerfor both local and foreign tourist. It has a lot of potential aspect to be polished over and brought out the best of Danau Toba.

Tourism spot is not limited to scenery-like experience. It can relate to the culture and many other attraction spot. Bataknese's culture and involvement on the area are still strong. Many tourist enjoyed their visit to experience directly to the authentic Batak Culture in Samosir Island.

There are four major strategies that can be used to develop competitive advantage in tourism development [4]. The first strategy is to build a landmark or flagship tourism 
spot that is aimed to become the region's symbolic icon [5]. We can relate to International example such as France's Eiffel Tower or America's 'Liberty' Statue. It is well-known across the world. The second strategy is to prepare the super-event that nowadays has been the common strategy to attract tourist all over the world [6]. The next strategy is called "thematisation" that build the tourism destination under a specific aspect to distinguish themselves from other. It mix the culture, sport, music, or arts and build a 'cultural city'. The last strategy is heritage mining. The heritage is rejuvenated and rebuilt in a creative package to attract people.

The existence of creative industry in tourism sector is important. Dahms' study [7] showed how the 'ghost town' or 'dying village' maximized their creative industry to regenerate themselves. Creative industry had become the key to initiate tourism spot $[8,9]$. Most part of Samosir Island is still under-developed which bring out its attractiveness to tourist. The development of creative industry over Danau Toba can be the key to promote Danau Toba to the world. However, creative industry should be built over by not only government, but also the locals' enterprises. Unfortunately, preparing the locals for creative industry development need a lot of attention. This paper is aimed to evaluate the current situation of Danau Toba's creative industries as well their preparation to support tourism.

\section{LITERATURE REVIEW}

\section{A. What is 'Creative Industry'?}

Creativity already acts as important role in economy. It can support economic growth and job creation. Linking the creative industries with tourism will stimulate tourism demand, bring out innovation in tourism experiences, improve tourism local products, recreating atmosphere and improve the destination's image.Creative industry is the new type of industry that sourced from cultivating people's creativity, talent, or skill to create a new products and/or job opportunities [10]. Creative industry plays important role in today global economy through its contribution to create a conducive business climate, expanding job opportunities, even positively increase the country's gross national product as whole.

Creative industry in context of tourism can be viewed as creative activities that link producers, consumers and destination by utilizing the available technology, people's talent and/or skill to implant intangible cultural products and experiences [11]. It is the industry that cultivate and combine intangible cultural aspect to the tangible product. The core sectors of the creative industries include: advertising, animation, architecture, design, film, gaming, gastronomy, music, performing arts, software and interactive games and television and radio.

\section{B. The Importance of Creative Industry in Tourism}

Creative industry will stimulate tourism growth as it add creative content in tourism experiences. It also will support a new and innovative approach for tourism development and creative marketing. Creative industry can help tourism sector to be rebuilt by influencing its image as people wishes. Advertising for example, it will help to embedthe destination's image in people's mind. According to OECD's report, creative industry in tourism offered opportunities to:

- Develop and distinguish one's tourism product and experience.

- Revitalize the current tourism product

- Enhance tourism experience

- Create atmosphere to 'buzz' the place

- Overcome the limitation of traditional tourism

In fact, creative industry also need tourism to support its innovation and create its market. Both synergies one with another. Creative industry is important to develop tourism and tourism is needed to implement the creative industy.

\section{Success Story of Creative industry in Tourism}

Can-Seng Ooi's work [12] showed the potential of creative industry to boost tourism in Singapore. Despite of have inadequate natural resources, not even fresh water for its own, creative industry is able to boost tourism in Singapore. Creative industry support the development of Singapore not only for product, but also the infrastructure. As result, many of tourism attracted to visit Singapore on their vacation time. Even many of Indonesian tourism come to visit Singapore on their holiday.

The successful story of creative industry in Singapore is not come without resistance. It is common that creativity and culture will always face any kind of resistance from management [13]. It requires cooperation from many stakeholders, especially on building infrastructures [14]. Creativity required to think out of the box which mean outside the routine. It is hard to apply something now outside of one's safe zone.

Another successful story that kind of interesting is Disney Land. Through creative industry, Disney nowadays capable to materialize its Disney character and culture to the real world. As result, many of Disney fan around the world visit Disney Land every day. It has become a fine tourism destination spot.

\section{Danau Toba as main Tourism Spot in North Sumatera}

Danau Toba is selected as main tourism spot in North Sumatera. It is located in Prapat and currently building its own airport to support tourism. The main attraction point of tourism in Danau Toba is the Toba Lake and Samosir Island which located on the middle of Toba Lake. The fresh scenery can mesmerize any tourist, even local people can be mesmerized every day. 
Indeed, the scenery and culture in Danau Toba, especially Samosir Island is fantastic. However, the existence of creative industry is still below noticeable. Locals treated the culture and tourism as different matter. Still it leaves a lot of room for improvement to act as main tourism spot. Scenery alone is not enough. Tourism experience is not only about scenery. It also including many other experience, such as cultural experience.

Danau Toba hold the best potential to be the main tourism spot in North Sumatera. However, a lot of improvement is needed to recreate Danau Toba as one of Indonesia's main tourism spot. Thus, cooperation from government, enterprises, and local is still needed.

\section{RESEARCH METHOD}

\section{A. Time and Place}

This study was conducted on many region of Danau Toba Tourism Spot for both Prapat and Samosir Island, including Tomok, Tuk-Tuk, BatuKursi, and Parbaba. The study was conducted from June 2017 to September 2017.

\section{B. The Participants}

In order to evaluate Danau Toba's creative industry situation, a number of 75 enterprises from Prapat and Samosir Island participated in this study.

\section{Data Collecting Method}

We interviewed the participant based on our structured questionnaires. The questionnaire was constructed to focus on their readiness to be North Sumatera's main tourism spot.

\section{Data Analysis Method}

A descriptive statistics is used to map the creative industries in Danau Toba. We evaluate their readiness based on the interview and our evaluation on their product. In this paper we describe their characteristics and readiness for creative tourism development.

\section{RESULT AND DISCUSSION}

\section{A. Creative Industry based on Business}

There are a lot of enterprises that existed in Danau Toba region. However, there is a tendency of the business sector based on the location. For example, many of Tuk-Tuk and Parbaba's enterprises that start hotel or restaurant business. For a tourism-attraction spot like Tomok and BatuKursi, a lot of locals start a souvenir and fashion line of business. It actually good for diversification from other region. However, too focused on both line of business and abandon the other is not a good choice. People will be in trouble to get other stuff that is not available in the region. Our mapping is summarized in Figure 1.

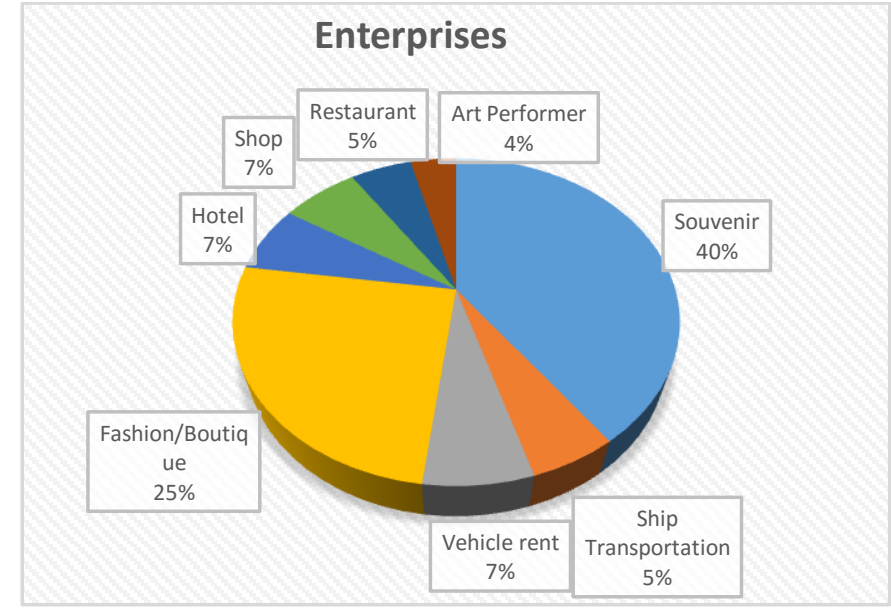

Figure 1. Enterprises Line of Business in Danau Toba

Figure 1 showed that most of Danau Toba's enterprises sells local souvenir or boutique. Fortunately locals already started to offer bike-for-rent that can help tourist. Indeed, souvenir from one's tourism spot is not separate-able in practice. Souvenir most of time act as the sign that someone had been traveled to one of tourism spot. According to Siahaan [15], as the number of similar enterprises increased, they will be more likely worked under competitive market which in long term, their profit will be zero. A good news that many kind of enterprises has already been established in Danay Toba. It can support one with another. However, less of them want to preserve the cultural factor. Only $4 \%$ of our enterprises that want to work as art performer. We can find small Batak Museum in Samosir. As the size is limited, it can also only preserve a little relic. Art performer can be found in BatuKursi or other tourism spot such as Tomok. The art-performer, sadly, far underdeveloped for an enterprises. Still, locals can pack the event in BatuKursi with art performer that satisfy their tourist. Our interview with locals stated that too much money oriented makes people forgot to preserve the heritage or creatively improve their performance while preserving its heritage and cultural value.

\section{B. Creative industry enterpriser based on gender}

Locals highly embraced the job-segregation culture. In one's family, men worked for livelihood while women do the domestic works. Our study showed that most of the enterpriser is women that want to help her husband for livelihood. Our result of enterpriser based on gender is summarized in Figure 2. 


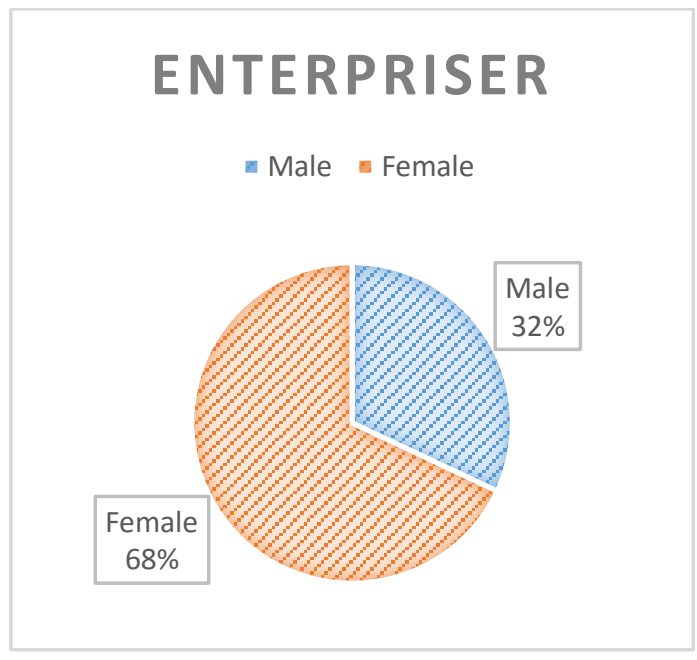

Figure 2. Enterprises Based on Gender

Figure 2 showed that the number of female enterpriser is doubled the number of male enterpriser. Mostly, on boutique and souvenir sector, were managed by female enterpriser. They believed that managing a shop can be done while keep on check their domestic work. Shop-keeping is rather unreliable, so the male (husband) worked for a fixed income while the female (spouse) worked for unreliable income from the shop. They believed that shop-keeping can be done while balancing their task both as spouse and enterpriser. As they worked for themselves, it is easier to manage their time for both role.

\section{Creative Industry Based on Working Experience}

Based on our study, the enterprises had been operate for a long time. Even several of our participant can not remember exactly when they start the business. They also operate as 'family business' that inherited from their parents.

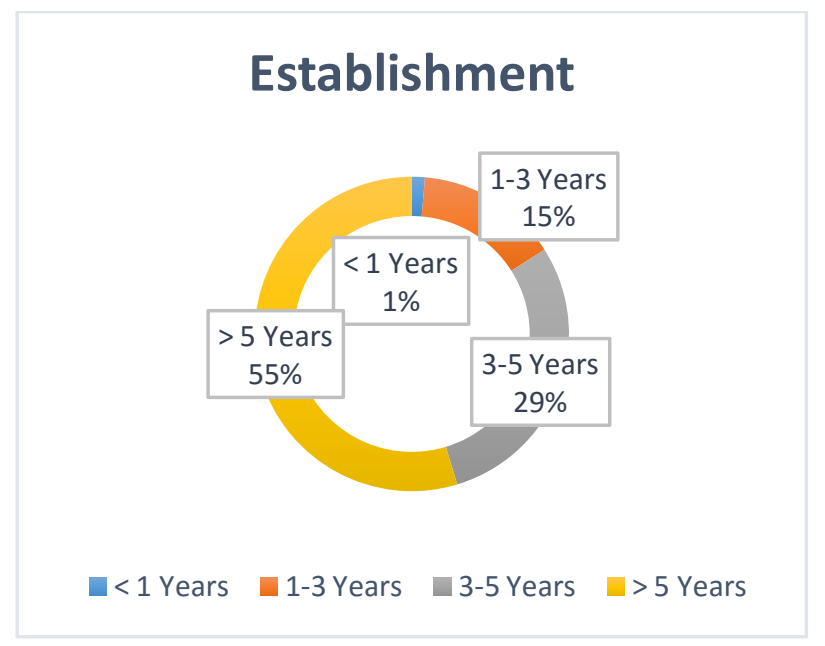

Figure 3. Enterprises Based on Operating Experience

Figure 3 showed that most of our enterprises had operated for more than five years. It had been a long time for a business to mature. Their accumulate experience helped them to face uncertainty. They become more sturdy and resistant to challenge. However, it is common that if one take on safe zone for too long, they will also resistant to change.

D. Creative industry enterpriser based on educational attainment

Education played an important role to enhance one's creativity. However, in today working environment, education also forced someone to start a business. Less organization accepting people that has a low educational attainment. Thus, they forced to start a business to support their livelihood. These situation is still paradox in Indonesia.

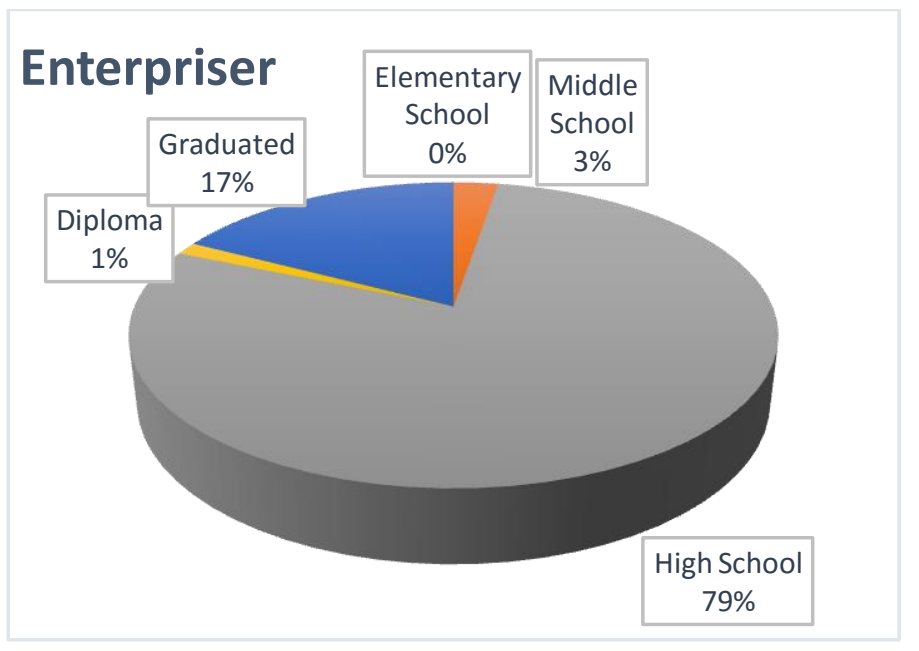

Figure 4. Enterpriser Based on Educational Attainment

Figure 4 showed that, indeed, most of our enterprises' educational attainment was high school (79\%). Only 17\% of graduated student (Strata 1) willing to start the business. Many study stated that enterprises help the economy to grow, but less people want to start the enterprises. They commonly want to be an employee as it gave a fixed income rather than enterprises that generate unreliable income.

\section{E. Creative industry enterpriser based on marital status}

Enterprises' characteristic based on marital status can show the information of their motivation to start and running the business. Basically, the married one need a lot more daily needs and a bigger economic responsibility to the family than the one who is not yet married. 


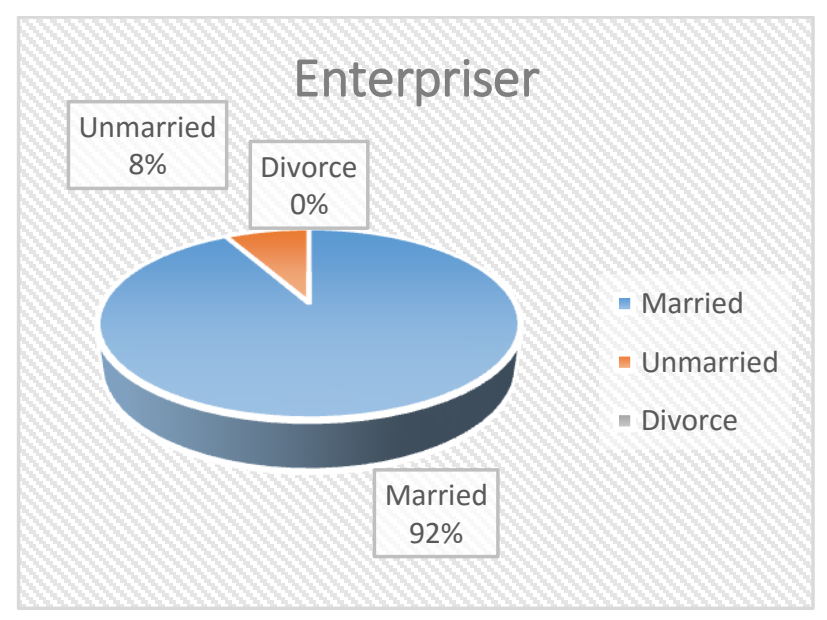

Figure 5. Enterpriser Based on Marital Status

Figure 5 showed that more that $90 \%$ of our enterpriser had married. Their income from running a business will help them to fulfill the daily needs. Even though they stated that running a business is a side-job for them, it certainly help their economic situation. The urge to grow and successful can be one source of creative idea for business development that we need.

F. The Current Situation for Danau Toba's Creative Industries

This study focused on creative industry to support tourism experience and existence for Danau Toba Tourism Spot. Literature review showed how important one's creative industry to help tourism as whole. In fact, tourism and creative industries mutually helped one another. Our study evaluated their readiness to accept the challenge and cultural infused in business.

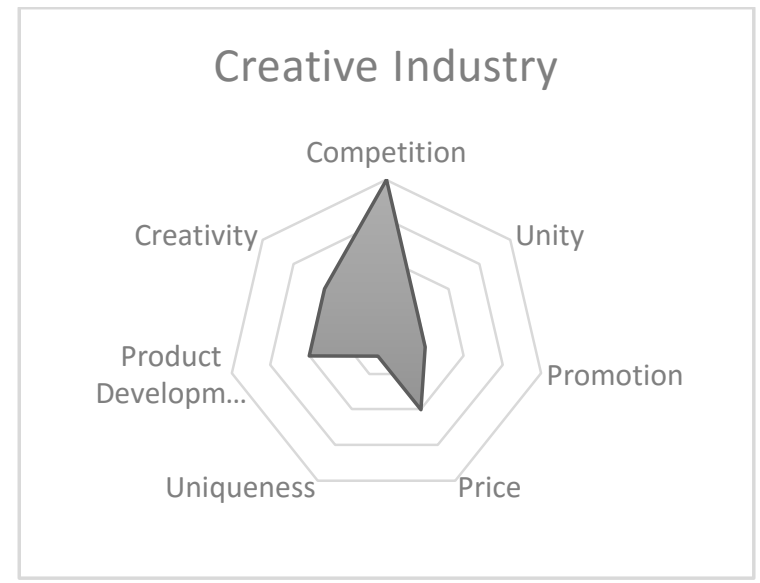

Figure 6. Overall Creative Industry Readiness

\section{The Competition}

Our mapping study showed that most of the industry approaching a perfectly competitive market, especially on boutique and souvenir sector. It is important to keep the competition among enterprises healthy. An unhealthy competition market eventually hinder the ability to grow and improve one's self. It is important to keep the sustainability of creative industry.

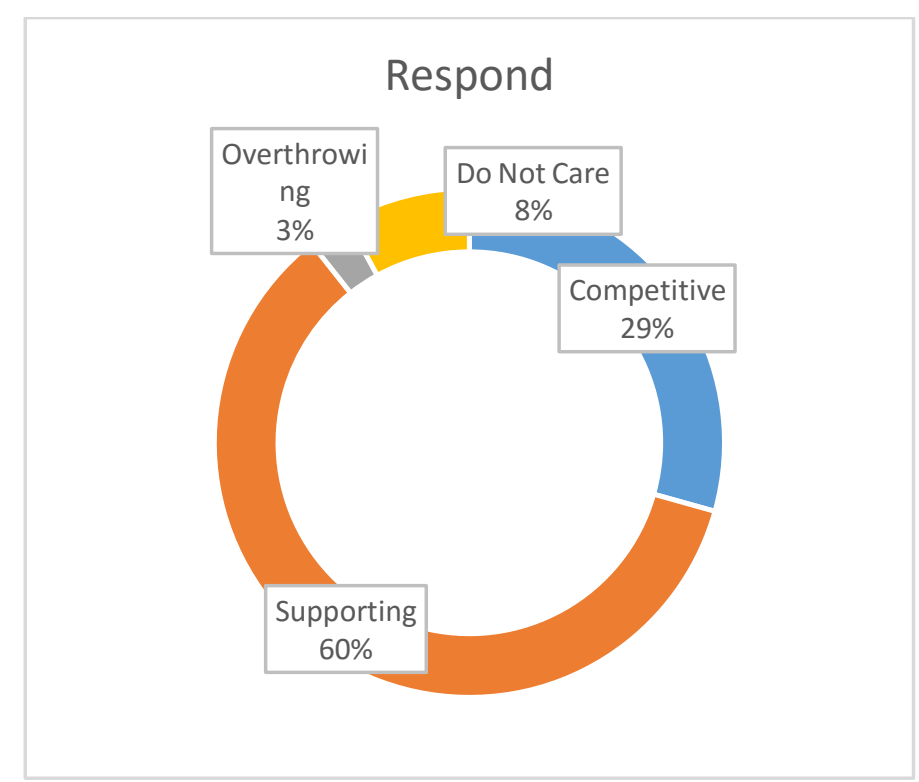

Figure 7. Enterprisers' Opinion on Market Competition

Figure 7 showed that overall market competition is good enough. They willingly helped one with another enterprise in term of customer or any information related to business. For example, they are willing to give their customer to the competitor to help both customer and competitor. If not, they asked their friendly competitor for their customers' need and retrieve it from them. Still, price war is existed in normal competitive market. As the market is mostly homogenous, the customer can easily compare the price from one to another shop. We should take a note that our study showed that several enterpriser is willingly to throw up their profit only for take away other customer, even under others' negotiation. It is advisable to improve the price war policy for the future. It is unhealthy that can kill creativity. Creativity is the costly resources that is needed for improvement. Price war can stop creativity growing in the market and product development. Overall, they are ready in term of competition.

Unity

Our study showed that all of the enterprises believed that they need to unify themselves to create a bigger, larger market to attract tourist better. They realized that unifying many of enterprises create a better shopping experiences for the customers. They also will be able to control the price better, for both pressing the price to customer and procuring the materials.

Local's activity to unify the enterprisers, however, is not applicable yet. Their sense of independency still low. They believed that it was government's role to facilitate and regulate the market. They will follow, but under the help of government. The contradiction is still growing today. 
Mentally, they are prepared to make a better creative industry for tourism. They are not ready in practice.

\section{Promotion}

Promotion is an important aspect to generate demand. Marketing gurus [16] stated that promotion is the key activity to attract customers. Our study showed that their promotion of the product is below noticeable. Actually the promotion is quite good for the hotels and restaurant line of business. They had already integrated themselves under Traveloka system that helped tourist to look for their hotel and restaurants. They also prepare the package to help tourist enjoy their vacation better. Unfortunately, other that hotels and restaurant, there were almost none promotion were made.

Our study also showed a creative promotion had been made that imbued Batak culture to attract customers. Many of ferry from Prapat to Samosir Island designed with the art of Batak culture. They also added Batak music to their facilities. We interviewed several tourist including foreign one and they appreciate and like the concept. It is one step closer to creative industry in Danau Toba.

\section{Price}

The price for most of goods and services in Danau Toba and Samosir Island is different based on the holiday season. The rate is set higher than normal under holiday season. Certainly, it boost their income. On average day, they can only cover daily needs. However on holiday season they can even make a saving. It is commonly happened on any sector of tourism activities, even airplane fare was higher on holiday season. The biggest problem of these prices is that they become too pricey. They also exercised a different price for different customer. It build people's distrust to the enterprises. Bargaining is normal, but it is more advisable to create a cut clear of price range. It will help creative industry to grow.

\section{Uniqueness}

The aspect that differ one product with the other is its uniqueness. The unique one will never be the same with other. However, our target of uniqueness is enough if they were a specialized local product. Unfortunately, our study showed that more that $80 \%$ of our enterprises do not have the uniqueness characteristics, not even close to the local culture.

Our interview found that the goods that were sold in all over Danau Toba was supplied from Java. The main reason is cost-efficiency. They can sell a souvenir-like product for a cheaper price. Creating a local product one is pricey. It cost a lot to embed the culture in local product. For example, the cost for Ulos will be too pricey to be sold as souvenir.

We believed that uniqueness is pricey as well. The more unique one's product, it required more skills and talent to be made. For example, one's painting will never be the same even if the same artist who made it. Creative industry is born to overcome this problem. However the current readiness in term of uniqueness is below the safe line.

\section{Demand-driven Product}

Our mapping study showed that most of enterprises had been established for a long time. As they stayed the same for long time. It will be harder to accept the change, especially to change one's product or process to satisfy he market's demand.

Table 1 Demand-driven Product Development Activity

\begin{tabular}{|c|l|c|}
\hline No & \multicolumn{1}{|c|}{ Respond } & \% \\
\hline 1 & Applied & 22 \\
\hline 2 & $\begin{array}{l}\text { In concept, but mostly } \\
\text { unrealized }\end{array}$ & 35 \\
\hline 3 & Not interested & 43 \\
\hline \multicolumn{2}{|c|}{ Total } & 100 \\
\hline
\end{tabular}

Table 1 showed that only $22 \%$ of our enterprises that willingly adopt themselves for the change. Most of time they relied on supplier for a change. They believed that the supplier know it better than themselves for market demand.

\section{Creativity}

Creative industry required the unification of culture and tourism industry product. As they resistant to change, they naturally resistant to imbued the product with Batak-culture like attributes. However, many of enterprises, outside the boutique and souvenir pushed their creativity to mix culture and product. Nowadays, we can learn Batak original script from the museum or even road sign in Prapat and Samosir. The art performer also started daily event in BatuKursi that can be enjoyed by tourist. They also invited the tourist to involved in cultural event rather than watch them from afar.

\section{CONCLUSION}

The existence of creative industry is important to support tourism industry. In fact, to create a better tourism experience, creative industry's work is needed. Creative industry will also be benefitted from successful tourism. However, the readiness of our enterprises' creative industry development is still low. The only key point to face the creative industry challenge was only their competition on market. Their creativity and promotion were still growing but the uniqueness was far under the radar. The biggest challenge to our enterprises is their independency as creator. They relied on government too much to develop themselves. They need to take initiative to grow bigger and be more creative. 


\section{ACKNOWLEDGMENT}

Authors gratefully acknowledge that the presented research is supported by Universitas Sumatera Utara (USU). This research is under research grant Non-PNBP USU 2017.

\section{REFERENCES}

[1] BadanPusatStatistik, PerkembanganPariwisatadanTransportasi Nasional. Jakarta: BadanPusatStatistik, 2015

[2] J. Spillane, Pariwisata Indonesia (SiasatEkonomidanRekayasaKebudayaan), $\quad$ Yogyakarta: Kanisius, 1994

[3] PresidenRepublik Indonesia. Undang-UndangNomor 10 Tahun 2009 tentangKepariwisataan. Jakarta: Sekretarian Negara RI, 2009

[4] G. Richards, and J. Wilson, "Developing creativity in tourist experiences: A soulution to the serial reproduction of culture", in Tourism Mangement, Volume 27, 2006

[5] G. Evans, "Hard-branding the cultural city-from Prado to Prada", in International Journal of Urban and Regional Research, Volume 27, 417-440, 2003

[6] J. Kurtzman, "Economic impact: Sport tourism and the city", in Journal of Sports Tourism, Volume 10, 47-71, 2005

[7] F.A. Dahms, "Dying villages, counterurbanization and the urban field: A Canadian perspective", in Journal of Rural Studies, Volume 11, 21-33, 1995

[8] M. Jayne, "Culture that works? Creative industries develompent in a working-class city", in Capital \& Class, 199-210, 2004

[9] C.M. Rogerson, "Creative industries and urban tourism: South African perspectives", in Urban Forum, Volume 17, 149-164, 2006

[10] DepartemenPerdaganganRepublik Indonesia, StudiIndustriKreatif Indonesia 2009, Jakarta: DepartemenPerdaganganRepublik Indonesia, 2009

[11] OECD Studies on Tourism, Tourism and the Creative Economy, OECD Publishing, 2014

[12] C. Ooi, "Creative industries and tourism in Singapore", in Tourism, Creativity, and Development, Canada: Rouletge, 2007

[13] H.L. Hughes, "Theatre in London and the inter-relationship with tourism", in Tourism Mangement, Volume 19, 445-452, 1998

[14] S. Roodhouse, and M.O. Mokre, "The Museums Quartier, Vienna: An Austrian cultural experiment", in International Journal of Heritage Studies, Volume 10, 193-207, 2004

[15] E.

KonsepdanPenerapanEkonomiManajerialdalamBisnis, Medan: USU Press, 2015

[16] Kotler, Philip dan Kevin Lane Keller. 2012. Marketing Management, 14th Edition. New Jersey: Prentice Hall. 